\title{
PENGARUH MARJIN LABA BERSIH DAN PENGEMBALIAN ATAS EKUITAS TERHADAP HARGA SAHAM PERUSAHAAN INDUSTRI BARANG KONSUMSI
}

\author{
Sari Nuzullina Rahmadhani $a^{*}$ \\ ${ }^{a}$ Fakultas Ekonomi dan Bisnis, Universitas Medan Area
}

Diterima Agustus 2019; Disetujui September 2019; Dipublikasikan November 2019

\begin{abstract}
Abstrak
Penelitian ini bertujuan untuk mengetahui dan menganalisis pengaruh antara marjin laba bersih dan pengembalian atas ekuitas terhadap harga sahan baik secara parsial maupun secara simultan pada perusahaan industri barang konsumsi yang terdaftar di Bursa Efek Indonesia (BEI). Populasi dalam penelitian ini adalah perusahaan industri barang konsumsi yang terdaftar di Bursa Efek Indonesia periode 2012-2016 yaitu berjumlah sebanyak 37 perusahaan. Jenis penelitian ini adalah penelitian asosiatif kausal. Teknik pengambilan sampel dalam Penelitian ini adalah teknik purposive sampling, yaitu teknik sampling berdasarkan kriteria tertentu. Sampel yang diperoleh dalam penelitian ini adalah berjumlah sebanyak 22 perusahaan. Pengujian yang digunakan dalam penelitian ini adalah uji asumsi klasik normalitas, multikolinieritas, heteroskedastisitas dan autokorelasi dan uji hipotesis uji koefisien korelasi \& determinasi, uji t, dan uji F. Hasil penelitian menunjukkan bahwa secara simultan variabel marjin laba bersih dan pengembalian atas ekuitas berpengaruh signifikan terhadap harga saham pada perusahaan industri barang konsumsi di Bursa Efek Indonesia. Sedangkan secara parsial, variabel marjin laba bersih berpengaruh positif dan signifikan terhadap harga saham dan variabel pengembalian atas ekuitas berpengaruh positif dan signifikan terhadap harga saham.
\end{abstract}

Kata Kunci : Margin Laba bersih, Perusahaan Barang Konsumsi, Pengembalian Ekuitas

\begin{abstract}
This research aims to detemine the effect of net profit margin and return on equity to the stock price on consumer goods industry listed on the Indonesia Stock Exchange. Independent Variables are net profit margin and return on equity. Dependent Variable is stock price. The population in this research are all consumer goods industries listed on the Indonesia Stock Exchange during the period 2012 to 2016 as much as 37companies.The type of this research is associative causal. The sampling technique was purposive sampling, which is based on certain criteria and got as much as 22 companies. The analysis used classic assumption testing, hypothesis testing, and linear regression. The results show that net profit margin and return on equity have positive effect and significant on stock price for simultaneous. And for partial, net profit margin has positive effect on stock price and return on equityhas positive and significant on stock price.
\end{abstract}

Keyword: Net Profit Margin, Consumer Goods, Return On Equity

How To Cite: Rahmadhani, S. N (2019)Pengaruh Margin Laba Bersih dan Pengembalian Atas Ekuitas Terhadap Harga Saham Perusahaan Industri Barang Konsumsi. Jurnal Akuntansi dan Bisnis: Jurnal Program Studi Akuntansi, 5 (2): $170-175$

* email: sarinuzullinarahmadhani@gmail.com

\section{PENDAHULUAN}

Keberadaan pasar modal di suatu negara bisa menjadi acuan untuk melihat tentang bagaimana bisnis negara yang bersangkutan dalam menggerakkan berbagai kebijakan 
ekonominya seperti kebijakan fiskal dan moneter (Erikawati, C. 2014). Menurut Fahmi (2014) Pasar modal merupakan tempat di mana berbagai pihak khususnya perusahaan menjual saham (stock) dan obligasi (bond) dengan tujuan dari hasil penjualan tersebut nantinya akan dipergunakan sebagai tambahan dana untuk memperkuat modal perusahaan. Menurut Mar'ati, F. S. (2012) pasar modal adalah pusat perdagangan utang jangka panjang dan saham perusahaan. Di Indonesia, transaksi pasar modal dilakukan melalui Bursa Efek Indonesia (BEI).

Setiap perusahaan yang listing di Bursa Efek Indonesia atau go public pasti menerbitkan saham yang dapat dimiliki oleh investor (Prabansari, Y., \& Kusuma, H. 2005). Go public adalah suatu perusahaan telah memutuskan untuk menjual sahamnya kepada publik dan siap untuk dinilai oleh publik secara terbuka. Dengan semakin banyak perusahaan yang melakukan IPO (Initial Public Offering) atau biasa disebut go public, akan mengundang para investor masuk dalam pasar saham. Investor yang berinvestasi di pasar modal pada dasarnya bertujuan untuk memperoleh keuntungan yang sebesarbesarnya (Nofrita, R. 2013). Keputusan investor di pasar saham memainkan peran penting dalam menentukan tren pasar, yang kemudian mempengaruhi perekonomian (Watung, R. W., \& Ilat, V. 2016).

Harga saham merupakan faktor yang sangat penting dan harus diperhatikan dalam melakukan investasi karna harga saham menunjukkan prestasi emiten. Pergerakan harga saham searah dengan kinerja emiten. Apabila emiten mempunyai prestasi yang semakin baik maka keuntungan yang dapat dihasilkan dari opersi usaha semakin besar. Pada kondisi yang demikian, harga saham emiten yang bersangkutan cenderung naik (Sudiyatno, B., \& Suharmanto, T. 2011). Harga saham terbentuk oleh supply dan demand. Wijiyanti, I., Anastasia, N., \& Gunawan, Y. W. (2003). menyatakan bahwa Harga saham dipengaruhi oleh faktor fundamental keuangan seperti analisis rasio marjin laba bersih dan rasio pengembalianatas ekuitas, tingkat suku bunga SBI, tingkat inflasi dan nilai tukar rupiah.

Menurut Hery (2016:198) marjin laba bersih (net profit margin) merupakan rasio yang digunakan untuk mengukur besarnya persentase laba bersih atas penjualan bersih. Jika rasio ini semakin tinggi maka semakin tinggi pula laba bersih yang dihasilkan dari penjualan bersih. Dengan demikian terjadi peningkatan kinerja manajemen dalam menghasilkan laba bagi perusahaan. Hal ini akan memicu kepercayaan Investor untuk menginvestasikan modalnya, dan jika semakin banyak yang membeli dan memiliki saham, maka harga saham akan naik. Pengembalian atas ekuitas (return on equity) adalah rasio penting bagi para pemilik dan pemegang saham karna rasio tersebut menunjukkan seberapa besar konstribusi ekuitas dalam menciptakan laba bersih (Herry, 2016). Sedangkan menurut Chrisna (2011)Kenaikan rasio pengembalian atas ekuitas biasanya diikuti oleh kenaikan harga saham perusahaan tersebut. Semakin tinggi pengembalian atas ekuitas berarti semakin baik kinerja perusahaan dalam mengelola modalnya untuk menghasilkan keuntungan bagi pemegang saham. Dimana hal ini akan dikaitkan dengan pembayaran dividen dan kenaikan harga saham.

Industri barang konsumsi merupakan salah satu sektor industri yang diperdagangan Bursa Efek Indonesia. sektor industri barang konsumsi mempunyai keterkaitan yang sangat erat dengan kebutuhan pokok manusia karena produknya dapat langsung diminati oleh konsumen. banyak investor yang tertarik untuk menanamkan modalnya di industri ini karena harga saham sektor industri barang konsumsi meningkat setiap tahun. Industri barang konsumsi mempunyai prospek yang sangat menjanjikan dan akan terus berkembang. Hal ini mengingat produk yang dihasilkan merupakan kebutuhan primer manusia dan jumlah penduduk Indonesia mencapai 258,7 juta jiwa. 
Permintaan akan produk industri barang konsumsi akan cenderung stabil yang berdampak pada kemampuan menghasilkan laba yang optimal. Sektor industri barang konsumsi terdiri atas 5 sub sektor yaitu sub sektor makanan dan minuman, sub sektor rokok, sub sektor farmasi, sub sektor kosmetik dan barang keperluan rumah tangga, serta sub sektor peralatan rumah tangga. Kenaikan indeks sektoral pada sektor industri barang konsumsi banyak didukung oleh emiten-emiten yang tergabung di dalamnya yaitu terdiri atas 37 perusahaan.

\section{METODE PENELITIAN}

Jenis penelitian yang dilakukan dalam penelitian ini adalah asosiatif kausal. Menurut Sugiyono (2016: 59), "Penelitian asosiatif kausal adalah suatu penelitian yang bertujuan menganalisis hubungan sebab akibat antara variabel independen (variabel yang mempengaruhi) dengan variabel dependen (variabel yang dipengaruhi)." Penelitian ini menguji pengaruh marjin laba bersih, dan pengembalian atas ekuitas terhadap harga saham. Marjin laba bersih dan pengembalian atas ekuitas merupakan variabel yang mempengaruhi,sementara harga saham merupakan variabel yang dipengaruhi. Lokasi penelitian ini adalah perusahaan industri barang konsumsi yang terdaftar di Bursa Efek Indonesia (BEI).

Populasi dalam penelitian ini adalah industri barang konsumsiyang terdaftar di Bursa Efek Indonesia (BEI) selama periode 2012-2016 yaitu berjumlah sebanyak 37 Perusahaan. Sampel dalam penelitian ini diambil berdasarkan teknik purposive sampling. "Teknik purposive sampling adalah teknik penentuan sampel dengan pertimbangan tertentu" (Sugiyono, 2016:124). Adapun kriteria sampel yang dikategorikan dalam penelitian ini adalah; perusahaan yang digunakan dalam penelitian ini industri barang konsumsi yang terdaftar di BEI. Perusahaan yang memiliki nilai marjin laba bersih yang bernilai positif, nilai pengembalian atas ekuitas yang bernilai positif selama periode 2012-2016. Perusahaan yang memiliki laporan keuangan yang lengkap dan sudah di audit selama periode 2012-2016. Perusahaan yang tidak delisting dan relisting selama periode 2012-2016. Perusahaan yang memiliki laba bersih selama periode 2012-2016. Perusahaan yang tidak pindah sektor industri selama periode 2012-2016. Berdasarkan kriteria-kriteria tersebut, maka jumlah perusahaan yang dapat digunakan untuk menjadi sampel berjumlah 22 perusahaan. Penelitian ini dilakukan dalam periode 5 tahun,di mana perusahaan tersebut berturut-turut terdaftar di Bursa Efek Indonesia periode tahun 2012-2016.

\section{HASIL DAN PEMBAHASAN}

\section{Pengaruh Marjin Laba Bersih terhadap Harga Saham}

Berdasarkan hasil penelitian, dapat diketahui bahwa pengaruh marjin laba bersih terhadap harga saham menunjukkan nilai t hitung sebesar 2,927 dan sig t sebesar 0,004. Sedangkan nilai t tabel sebesar 1.98238, yang berarti t hitung marjin laba bersih $>\mathrm{t}$ tabel $(2,927>1.98238)$ dan sig t sebesar $0,004<0,05$ sehingga $H_{0}$ ditolak $H_{1}$ diterima. Hal ini menunjukkan bahwa secara parsial variabel marjin laba bersih berpegaruh signifikan terhadap harga saham. Koefisien beta (koefisien regresi) variabel marjin laba bersih menunjukkan hubungan searah (positif) sebesar0,847. Pengaruh positif ini memiliki arti bahwa jika majin laba bersih naik sebesar 1\% maka akan meningkatkan harga saham sebesar 0,847,dan sebaliknya jika marjin laba bersih turun sebesar 1\%, maka akan menurunkan harga saham sebesar 0,847 . Nilai standar error < nilai beta $(0,290<0,847)$ 
yang berarti bahwa variabel marjin laba bersih memiliki persamaan regresi yang sangat baik dalam memprediksi harga saham serta bersifat elastis terhadap perubahan variabel harga saham.

Semakin besar Marjin laba bersih maka akan menunjukkan kinerja perusahaan yang produktif untuk memperoleh laba yang tinggi melalui tingkat penjualan tertentu serta kemampuan perusahaan yang baik dalam menekan biaya-biaya operasionalnya. Hal ini meningkatkan kepercayaan para para investor dan tertarik untuk membeli saham tersebutsehingga menyebabkan harga saham akan naik. Hal ini sejalan dengan penelitian yang telah dilakukan oleh hutami (2012), Rosdian Widiawati dan Ventje Ilat (2016)yang menyimpulkan bahwa marjin laba bersih (net profit margin) memiliki pengaruh positif dan signifikan terhadap harga saham.

\section{Pengaruh Pengembalian atas Ekuitas terhadap Harga Saham}

Berdasarkan hasil penelitian, dapat diketahui bahwa pengaruh pengembalian atas ekuitas terhadap harga saham menunjukkan nilai $t$ hitung sebesar 3,282 dan sig $t$ sebesar 0,001 . Sedangkan nilai t tabel sebesar 1,98238t hitung pegembalian atas ekuitas $>t$ tabel $(3,282>1,98238)$ dan sig $t$ sebesar $0,001<0,05$ sehingga $\mathrm{H}_{0}$ ditolak $\mathrm{H}_{1}$ diterima.Hal ini menunjukkan bahwa secara parsial variabel pengembalian atas ekuitas berpegaruh signifikan terhadap harga saham. Koefisien beta (koefisien regresi) variabel pengembalian atas ekuitas menunjukkan hubungan searah (positif) sebesar0,883. Pengaruh positif ini memiliki arti bahwa jika pengembalian atas ekuitas mengalami kenaikan 1\%, maka harga saham (Y) akan mengalami peningkatan sebesar 0,883 dan sebaliknya jika pengembalian atas ekuitas turun sebesar 1\%, maka akan menurunkan harga saham sebesar0,883. Nilai standar error < nilai beta $(0,269<0,883)$ ) yang berarti bahwa variabel pengembalian atas ekuitas memiliki persamaan regresi yang sangat baikdalam memprediksi harga saham serta bersifat elastis terhadap perubahan variabel harga saham.

Hal ini menunjukkan bahwa secara parsial variabel pengembalian atas ekuitas memiliki pengaruh positif dansignifikan terhadap harga saham. Menurut Syamsuddin (2011: 64), "Pengembalian atas ekuitas merupakan suatu pengukuran dalam penghasilan (income) atas modal yang diinvestasikan dalam perusahaan." Jadi, rasio pengembalian atas ekuitas digunakan untuk mengukur efektivitas perusahaan dalam menghasilkan keuntungan dengan memanfaatkan modal yang dimiliki perusahaan. Rasio ini menunjukkan kesuksesan manajemen dalam memaksimalkan tingkat pengembalian yang lebih besar kepada pemegang saham. Informasi peningkatan rasio pengembalian atas ekuitas akan diterima pasar sebagai sinyal baik yang akan memberikan masukan positif bagi investor dalam pengambilan keputusan membeli saham. Hal ini sejalan dengan penelitian yang telah dilakukan oleh Musalamah dan Isa (2015)yang menyimpulkan bahwa pengembalian atas ekuitas (return on equity) memiliki pengaruh positif dan signifikan terhadap harga saham.

\section{Pengaruh Marjin Laba Bersih dan Pengembalian atas Ekuitas terhadap Harga Saham}

Berdasarkan pengujian yang telah dilakukan, diketahui bahwa pengaruh marjin laba bersih dan pengembalian atas ekuitas terhadap harga saham secara bersama-sama menunjukkan nilai $F$ hitung 46,363. Sedangkan nilai $F$ tabel sebesar 3,08. Hal ini berarti F hitung $>\mathrm{F}$ tabel $(46,363>3,08)$ dengan tingkat signifikansi $0,000<0,05$ maka $\mathrm{H}_{0}$ diterimaH $_{1}$ ditolak. Kesimpulannya bahwa marjin laba bersih dan pengembalian atas ekuitas secara bersama-sama berpengaruh signifikan terhadap harga saham. Oleh sebab itu, Investor perlu menganalisis kedua faktor ini sebelum mengambil keputusan untuk 
Rahmadhani, S. N (2019)Pengaruh Margin Laba Bersih dan Pengembalian Atas Ekuitas Terhadap Harga Saham Perusahaan Industri...

menanamkan modalnya karena dalam penelitian ini telah terbukti bahwa marjin laba bersih dan pengembalian atas ekuitas secara bersama-sama berpengaruh signifikan terhadap harga saham.Variabel yang paling berpengaruh terhadap harga saham adalah pengembalian atas ekuitas yang ditentukan berdasarkan t hitung tiap variabel. Dan yang memiliki nilai t hitung tertinggi adalah pengembalian atas ekuitas sebesar 3,282.

\section{SIMPULAN}

Dari hasil analisis regresi yang telah dilakukan terhadap variabel-variabel yang mempengaruhi harga saham pada perusahaan industri barang konsumsi yang terdaftar di Bursa Efek Indonesia, maka penelitian ini dapat berbagai kesimpulan yakni; variabel marjin laba bersih berpengaruh positif dan signifikan terhadap harga saham. Hal ini dapat dilihat dari nilai $t$ hitung marjin laba bersih $>t$ tabel $(2,927>1.8238)$ dan sig $t$ sebesar 0,004<0,05. Artinya, Semakin besar Marjin laba bersih maka akan menunjukkan kinerja perusahaan yang produktif untuk memperoleh laba yang tinggi melalui tingkat penjualan tertentu serta kemampuan perusahaan yang baik dalam menekan biaya-biaya operasionalnya. Hal ini meningkatkan kepercayaan para para investor dan tertarik untuk membeli saham tersebut sehingga menyebabkan harga saham akan naik. Kemudian, variabel pengembalian atas ekuitas berpengaruh positif tetapi dan signifikan tehadap harga saham. Hal ini dapat dilihat dari $t$ hitung pegembalian atas ekuitas $>\mathrm{t}$ tabel $(3,282>1.99300)$ dan sig t sebesar 0,001<0,05. Artinya, Rasio pengembalian atas ekuitas menunjukkan kesuksesan manajemen dalam memaksimalkan tingkat pengembalian yang lebih besar kepada pemegang saham. Informasi peningkatan rasio pengembalian atas ekuitas akan diterima pasar sebagai sinyal baik yang akan memberikan masukan positif bagi investor dalam pengambilan keputusan membeli saham. Serta yang terakhir bahwa ariabel marjin laba bersih, pengembalian atas ekuitas dan kurs dollar secara bersama-sama berpengaruh signifikan terhadap harga saham. Hal ini dapat dilihat dari nilai $\mathrm{F}$ hitung $>\mathrm{F}$ tabel $(46,363>3,08)$ dengan tingkat signifikansi $0,000<0,05$. Oleh sebab itu, investor harus menganalisis kedua faktor ini sebelum menanamkan modalnya. Dan variabel yang paling dominan berpengaruh terhadap harga saham adalah variabel pengembalian atas ekuitas dengan nilai t hitung sebesar 3,282.

\section{DAFTAR PUSTAKA}

Arum Deswati Murni Musalamah dan Muzakar Isa. (2015). PengaruhEarning Per Share, Debt to Equity Ratio, dan Return on Equity Terhadap Harga Saham pada Perusahaan Manufaktur yang Terdaftar di Bursa Efek Indonesia Tahun 2007-2011. Jurnal Managemen dan Bisnis, Volume 19, Nomor $2 . \quad$ Hlm. 189-195.

David Kodrat Sukardi dan Kurniawan Indonanjaya. 2010. Manajemen Investasi: Pendekatan Tekhnikal dan Fundamental untuk Analisis Saham, Cetakan Pertama, Graha Ilmu, Yogyakarta.

Erikawati, C. (2014). Analisis Pengaruh Economic Value Added (EVA) dan Rasio Profitabilitas terhadap Harga Saham di Perusahaan Manufaktur (Studi Kasus Perusahaan Food and Beverages dan Consumer Goods yang Go Public di Bursa Efek Indonesia 2007-2011) (Doctoral dissertation, Universitas Muhammadiyah Surakarta).

Fahmi, Irfan. 2014. Manajemen Keuangan Perusahaan dan Pasar Modal, Edisi Pertama, Mitra Wacana Media, jakarta.

Ghozali, Imam. 2013. Aplikasi Analisis Multivariate dengan Program SPSS21. Edisi7, BP Universitas Diponegoro, Semarang

Hadi, Nor. 2013. Pasar Modal: Acuan Teoritis dan Praktis Investasi di Instrumen Keuangan Pasar Modal, Graha Ilmu, Yogyakarta.

Hanafi, Mamduh M. 2009. Manajemen Keuangan, Edisi Keempat. BPFE, Yogyakarta.

Heriyati Christina. (2011). Pengaruh Return on Equity, Net Interest Margin dan Divident Payout Terhadap Harga Saham Perbankan di Bursa Efek Indonesia. Tesis, Magister Akuntansi Sekolah Pascasarjana Universitas Sumatera Utara. 
Hery. 2016. Analisis Laporan Keuangan. PT Grasindo, Jakarta.

Husnan, Suad. 2013. Teori Portofolio dan Analisis Sekurita,, Sekolah Tinggi Ilmu Manajemen YKPN, Yogyakarta.

Hutami, R. P. (2012). Pengaruh Dividen Per Share, Return On Equity, dan Net Profit Margin Terhadap Harga Saham Perusahaan Industri Manufaktur Yang Tercatat Di Bursa Efek Indonesia Periode 20062010. Jurnal Nominal. Volume 1, Nomor 1.

Jogiyanto. 2008. Teori Portofolio dan Analisis Investasi, Edisi Ketiga. BPFE, Yogyakarta.

Mar'ati, F. S. (2012). Analisis Efisiensipasar Modal Indonesia. Jurnal Ilmu Manajemen dan Akuntansi Terapan (JIMAT), 3(2), 35-44.

Nofrita, R. (2013). Pengaruh Profitabilitas terhadap Nilai Perusahaan dengan Kebijakan Deviden sebagai Variabel Intervening (Studi Empiris pada Perusahaan Manufaktur yang Terdaftar di BEI). Jurnal Akuntansi, 1(1).

Nur Aminah, Rina Arifati, Agus Supriyando (2016). Pengaruh Dividend Per Share, Return on Equity, Net Profiit Margin Return on Investment dan Return on Asset Terhadap Harga Saham Perusahaan Real Estate dan Property Yang Terdaftar di Bursa Efek Indonesia Periode 2011-2013. Jurnal of Accounting,Volume 2, Nomor 2, Maret 2016.

Prabansari, Y., \& Kusuma, H. (2005). Faktor-Faktor yang Mempengaruhi Struktur Modal Perusahaan Manufaktur Go Public di Bursa Efek Jakarta. Jurnal Fakultas Hukum UII.

Rescyana Putri Hutami. (2012). Pengaruh Dividend Per Share, Return on Equity dan Net Profiit Margin Terhadap Harga Saham Perusahaan Industri Manufaktur Yang Tercatat di Bursa Efek Indonesia Periode 2006-2010. Jurnal Nominal,Volume 1, Nomor 1, Hlm. 104-123.

Rosdian Widiawati Watung dan Ventje Ilat. (2016). PengaruhReturn on Asset, Net Profiit Margin dan Earning Per Share Terhadap Harga Saham pada Perusahaan Perbankan di Bursa Efek Indonesia Periode 2011-2015. jurnal EMBA,Volume 4, Nomor 2, Juni 2016. Hlm. 518-529.

Sudiyatno, B., \& Suharmanto, T. (2011). Kinerja Keuangan Konvensional, Economic Value Added, dan Return Saham. Jurnal Dinamika Manajemen, 2(2).

Sugiyono. 2016. Metode Penelitian Pendidikan, Cetakan Kelima belas, Alfabeta, Bandung

Watung, R. W., \& Ilat, V. (2016). Pengaruh Return On Asset (Roa), Net Profit Margin (Npm), Dan Earning Per Share (Eps) Terhadap Harga Saham Pada Perusahaan Perbankan Di Bursa Efek Indonesia Periode 2011-2015. Jurnal EMBA: Jurnal Riset Ekonomi, Manajemen, Bisnis dan Akuntansi, 4(2).

www.idx.co.id

www.duniainvestasi.com 